\title{
Optimalisasi Gula Cair dan pH Medium untuk Fermentasi Alkohol dari Jus Curucuma xanthorihiza
}

\author{
The Optimalization of Liquid Sugar and pH Medium for Alcohol Fermentation of \\ Curucuma xanthorihiza Juice
}

\section{Patricius Kianto Atmodjo}

Fakultas Teknobiologi Universitas Atma Jaya Yogyakarta, Yogyakarta

Email: Patriatmodjo65@gmail.com

\begin{abstract}
Liquid sugar is a new product of sugar which consists of fructose, glucose and disaccaharide. It is used as carbon and energy source in Temulawak (Curcuma xantorhiza Raoxb) fermentation to produce alcohol by Saccharomyces cerevisiae. The aim of this research was to find out the liquid sugar concentration and $\mathbf{p H}$ medium used to alcohol fermentation. Eight liters of water was added one kilogram temulawak, boiled for 30 minutes. Then, the liquid filtrate was added sugar $(0,15,30,45,60$ and $75 \%)$. The $\mathrm{pH}$ filtrate was arranged to be $4-6(4,4.5,5,5.5,6)$. Then $1 \mathrm{~g}$ powder of $S$. cerevisiae was added to each treatment. The fermentation was conducted in room temperature. The total biomass, $\mathrm{pH}$, and residual sugar were measured three times every day. The alcohol was measured after thirty day of fermentation. The result showed that the total biomass, $\mathrm{pH}$ and residual sugar were not correlated wih sugar concentration, but the increasing of alcohol was correlated significantly with sugar concentration. The optimum sugar concentration was $45 \%$, eficient ratio sugar/alcohol was more than $3 \%$, and the optimal of pH medium was 5 which produced the highest concentrate alcohol.
\end{abstract}

Keywords: alcohol, liquid sugar, $\mathrm{pH}$, temulawak, Saccharomyces cerevisiae

\begin{abstract}
Abstrak
Gula cair suatu produk baru dari gula yang tersusun dari fruktosa, glukosa dan disakarida dianggap lebih baik daripada gula kristal. Penelitian ini bertujuan untuk mengetahui konsentrasi gula cair dan $\mathrm{pH}$ medium yang digunakan dalam fermentasi sari temulawak (Curcuma xantorhiza Raoxb) oleh Saccharomyces cerevisiae untuk memproduksi alkohol. Satu kg temulawak kering dihancurkan ditambah air sebanyak 8 liter, ditambahkan $250 \mathrm{~g}$ kecambah kacang hijau, direbus selama 30 menit, lalu didinginkan kemudian direbus lagi tiga kali rebusan disaring lalu diambil airnya kemudian dimasukkan ke dalam botol fermentasi sebanyak 300 ml kemudian ditambahkan gula cair sehingga diperoleh variasi $0,15 \%, 30 \%$, $45 \%, 60 \%$ dan $75 \%$. Medium sari temulawak ini diatur $\mathrm{pH}$ nya menjadi 4, 4,5, 5,0, 5,5 dan 6 . Selanjutnya $1 \mathrm{~g}$ bibit $S$. cerevisiae ditambahkan pada tiap botol fermentasi lalu ditutup. Fermentasi berlangsung pada suhu kamar. Parameter penelitian berupa total sel, pH dan gula reduksi yang diukur tiap sehari sebanyak tiga kali, dan kadar alkohol setelah satu bulan fermentasi. Hasil menunjukkan tidak adanya hubungan yang signifikan antara peningkatan kadar gula dan perbedaan pH medium terhadap total sel, perubahan pH dan kadar gula. Namun ada hubungan yang nyata antara kenaikan kadar gula medium dengan alkohol yang dihasilkan. Efisiensi konversi gula menjadi alkohol tertinggi di atas $3 \%$ terjadi pada fermentasi pada konsentrasi gula $45 \%$. Kadar alkohol tertinggi dihasilkan pada pH medium awal 5.
\end{abstract}

Kata kunci: alkohol, gula cair, pH, temulawak, Saccharomyces cerevisiae

Diterima: 30 Agustus 2017, disetujui: 29 September 2017 


\section{Pendahuluan}

Alkohol merupakan salah satu bahan kimia yang sangat dibutuhkan untuk industri manufaktur dan kesehatan, bahkan untuk produksi makanan, baik sebagai pelarut maupun perasa. Alkohol dapat diproduksi secara fermentasi oleh berbagai mikroba menggunakan bahan baku yang mengandung karbohidrat. Alkohol ini disebut bioalkohol atau bioethanol karena sebagian besar produknya adalah etanol. Efisiensi produksi bioetanol diperoleh melalui ketepatan pemilihan jenis mikroorganisme, bahan baku, dan kontrol proses fermentasi.

Selama ini fermentasi alkohol menggunakan molase atau tetes yang merupakan sisa dari proses pengkristalan gula pasir yang masih mengandung gula dan asam-asam organik sebagai bahan baku. Dibandingkan bahan baku lain, molase mempunyai keunggulan yaitu selain harganya murah juga mengandung $50 \%$ gula sederhana yang dapat difermentasi langsung oleh khamir menjadi etanol tanpa pretreatment (Bergman, 2001).

Yumaihana dan Aini (2009), mengemukakan bahwa penggunaan molase sebagai bahan baku banyak kendala seiring dengan penurunan minat petani menanam tebu bahan baku industri sehingga memengaruhi keberlanjutan ketersediaan molase. Selain itu, molase ini juga digunakan berbagai macam industri sehingga terjadi persaingan dalam memperoleh molase yang mengakibatkan kenaikan harga dan harganya tidak murah bahkan tidak ekonomis untuk industri.

Di sisi lain, saat ini di pasar beredar suatu produk gula cair yang dianggap lebih aman, lebih manis, lebih sehat dan lebih murah. Gula cair ini merupakan hasil sakarifikasi tapioka (Rahmawati dkk., 2017). Komposisi gula cair ini adalah sebagian besar fruktosa dan glukosa yang seimbang serta disakarida dalam jumlah kecil. Harga gula cair ini relatif hampir sama dengan molase, dan saat ini mulai banyak digunakan untuk pembuatan sirup dan pemanis makanan.

Penelitian ini bertujuan untuk membuktikan bahwa gula cair dapat digunakan untuk sumber energi dan karbon bagi pertumbuhan Saccharomyces cerevisieae yang bekerja pada proses fermentasi alkohol menggunakan bahan baku sari temulawak. Penelitian sari temulawak untuk bahan fermentasi alkohol telah dilakukan oleh Pinem (1999) dan Atmodjo dkk. (2016). Pada peneletian terdahulu yang telah dilakukan oleh Atmojo dkk. (2016) telah menggunakan molase untuk fermentasi alkohol yang ditambah sari temulawak. Pada penelitian ini digunakan gula cair untuk mengganti molase sehingga ketergantungan terhadap molase dapat dihilangkan. Penelitian dilakukan optimalsiasi kadar gula cair dan $\mathrm{pH}$ yang digunakan, karena dua faktor ini menjadi faktor kunci keberhasilan suatu proses fermentasi. Saccharomyces cerevisiae sebagai agen fermentasi karena mikroba ini dianggap lebih baik, lebih kuat, dan lebih mudah perawatannya dibanding mikroba lain. Selain itu khamir ini tersedia pada berbagai mutu yang diperdagangkan.

\section{Metode Penelitian}

\section{Bahan}

Temulawak diperoleh dari pedagang bahan jamu di Pasar Bringhardjo Yogyakarta dalam bentuk criping temulawak yang kering bersih tidak berjamur. Khamir $S$. cerevisiae diperoleh dari toko bahan roti dalam bentuk kristal kering dari merek Fermipan yang biasanya digunakan untuk pengembang yang diperiksa dulu kebenaran dan kemampuan hidupnya. Taoge/kecambah kacang hijau umur 2 hari dibeli di pasar. Gula cair diperoleh dari toko bahan roti dengan kualitas baik, berwarna agak kekuningan, jernih, tidak berbau selain bau gula. Bahan kimia lain diperoleh dari laboratorium Teknobio-Industri Fakultas Teknobiologi Universitas Atma Jaya Yogyakarta, sedangkan bahan kimia untuk analisa gas kromatografi diperoleh laboratorium Kimia Analisa Jurusan Kimia Fakultas MIPA Universitas Gadjah Mada.

\section{Waktu dan Tempat Penelitian}

Penelitian ini berlangsung pada bulan April 2017 sampai dengan Agustus 2017 dilakukan di Laboratorium Teknobio-Industri Fakultas Teknobiologi Universitas Atma Jaya Yogyakarta untuk proses fermentasi dan pengukuran kadar gula, total biomassa, dan $\mathrm{pH}$. Sedangkan, untuk pengukuran kadar alkohol 
dilakukan di Laboratorium Kimia Analisa Jurusan Kimia Fakultas MIPA universitas Gadjah Mada.

\section{Pembuatan Sari Temulawak}

Satu kilogram keping temulawak kering dihancurkan lalu ditambah air 8 liter dan $250 \mathrm{~g}$ kecambah kacang hijau direbus menggunakan panci biru lurik selama 30 menit, kemudian didinginkan. Keesokan harinya hasil rebusan tersebut direbus lagi. Proses perebusan dilakukan sampai tiga kali untuk membunuh kontaminan. Selanjutnya, dilakukan penyaringan untuk memperoleh filtrat cair sebagai bahan baku stok fermentasi (Pinem, 1999 dan Atmodjo dkk. 2016).

\section{Penentuan Kadar Gula Optimal}

Filtrat $\mathrm{pH}$ diatur menjadi sekitar 5. Kemudian filtrat ini dimasukkan ke dalam botol fermentasi sebanyak $300 \mathrm{ml}$. Selanjutnya, filtrat ditambah gula cair sesuai perlakuan sehingga diperoleh cairan temulawak berkadar gula 0,15 , 30, 45, 60 dan 75\%. Kemudian sebanyak $1 \mathrm{~g}$ bibit khamir $S$. cerevisiae dimasukkan ke dalam campuran untuk melakukan proses fermentasi. Kemudian botol ditutup, selang udara yang ada dimasukkan ke dalam botol penampung udara. Botol fermentasi ini diletakkan dalam ruang pada suhu kamar. Setiap hari dilakukan pengukuran $\mathrm{pH}$ menggunakan $\mathrm{pH}$ meter, kadar gula menggunakan alat refractometer, dan total biomassa menggunakan hemasitometer dan pengecatan metilen biru. Khusus bagi pengukuran kadar alkohol dilakukan setelah satu bulan menggunakan alat gas kromatografi (Sudarmadji dkk., 1997).

\section{Penentuan pH optimal}

Filtrat sari temulawak sebanyak $270 \mathrm{ml}$ ditambah $30 \mathrm{ml}$ gula cair, dihomogenkan lalu dimasukkan (dibagi) ke dalam 25 botol. Cairan temulawak dalam botol diatur $\mathrm{pH}$ nya sehingga terdapat variasi $\mathrm{pH}$ yaitu: $4 ; 4,5 ; 5 ; 5,5 ;$ dan 6 . Kemudian ditutup, selang diatur agar terendam dalam cairan penampung udara pada botol yang terpisah. Botol ini diletakkan dalam ruang di laboratorium. Fermentasi berlangsung pada suhu kamar. Selama tiga hari diukur menggunakan pH-meter, kadar gula dengan refractometer, dan total khamir menggunakan hemasitometer dengan pengecatan biru methil. Setelah 30 hari diukur kadar alkoholnya menggunakan alat Gas chromatography (Hamanti, 2000).

\section{Hasil dan Pembahasan}

\section{Optimalisasi Gula Cair Fermentasi Sari Temulawak}

Gula cair adalah gula dalam bentuk cairan larutan kental yang umumnya gabungan antara fruktosa dan glukosa. Gula ini harganya seimbang dengan molase sehingga berpotensi digunakan untuk bahan baku industri fermentasi. Seperti yang telah diketahui bahwa fermentasi adalah suatu proses perubahan kimia pada substrat organik, baik karbohidrat, protein, lemak atau lainnya, melalui kegiatan biokatalis atau enzim yang dihasilkan oleh mikrobia dan berlangsung dalam kondisi anaerob maupun aerob. Fermentasi anaerob adalah fermentasi yang tidak memerlukan oksigen, sedangkan fermentasi aerob adalah fermentasi yang berlangsung dalam suasana lingkungan beroksigen (Maurice, 2011). Fermentasi mempunyai pengertian aplikasi metabolisme mikroba untuk mengubah bahan baku menjadi produk yang bernilai tinggi, seperti biomassa, protein sel tunggal, asam-asam organik, antibiotika, dan biopolimer serta pengujian kemampuan konversi suatu mikroba (Nurdyastuti., 2006). Dalam industri fermentasi diperlukan substrat yang murah, mudah tersedia, dan efisien penggunaannya. Usaha selalu dilakukan untuk menemukan substrat baru yang lebih murah dan lebih baik, tetapi terkadang timbul masalah baru dalam hal cara penyimpanan, kemudahan untuk disterilisasi atau komposisi yang berbeda (Bergman, 2001).

Menurut Sabrina dkk., (2016), khamir seperti pula mikroorganisme yang lain memerlukan medium dan lingkungan yang sesuai untuk pertumbuhan dan perkembangbiakannya. Beberapa unsur merupakan dasar kehidupan, seperti karbon, hidrogen, oksigen, fosfor, potassium, zat besi, dan magnesium. Unsur karbon terutama diperoleh dari gula, sebagai sumber unsur nitrogen dapat digunakan amonia, garam amonium, peptida, nitrat, urea dan senyawa- 
senyawa ini tergantung pada jenis khamir. Fosfor merupakan unsur penting dalam kehidupan khamir, terutama dalam pembentukan alkohol dari gula, contohnya dalam pembentukan heksosa dan triosa fosfat (Maurice, 2011). Menurut Hatmanti (2000), bahan baku yang digunakan dalam pembuatan alkohol secara fermentasi dapat dibagi menjadi tiga macam, yaitu: bahan bergula seperti gula tebu, gula bit, tetes dan cairan buah-buahan; bahan pati yang terdiri dari bahan-bahan seperti padi-padian dan kentang; serta bahan selulosa seperti kayu.

Pada penelitian ini yang menguji bahan baru berupa gula cair terhadap pertumbuhan khamir dalam proses fermentasi alkohol menunjukkan hasil yang cukup beragam selama tiga hari pengamatan (pada Tabel 1-3). Pada perlakuan tanpa pemberian gula, khamir masih dapat tumbuh dikarenakan khamir mampu memanfaat gula alami dari temulawak, meskipun banyaknya sel yang tumbuh paling sedikit dibanding perlakuan seperti yang terlihat di Tabel 1. Penambahan kadar gula mula-mula meningkatkan pertumbuhan khamir, yang tertinggi terlihat pada kadar gula cair $60 \%$, kemudian turun cukup besar di saat kadar gula dinaikkan menjadi $75 \%$. Hal ini menunjukkan bahwa gula cair dapat digunakan sebagai medium dan sumber karbon untuk pertumbuhan khamir. Namun, jika terlalu besar maka akan menjadi racun dan menghambat pertumbuhan khamir yang menurun menjadi hanya 96 pada konsentrasi gula $75 \%$ waktu fermentasi 72 jam. Seperti yang telah diketahui kadar gula tinggi dapat digunakan untuk mengawetkan makan karena menghambat pertumbuhan mikroba dengan cara menaikkan tekanan osmosis kondisi di luar sel, sehingga bila ada sel hidup diletakkan akan mengalami dehidrasi dan plasmolisa (Lin dkk., 2012).

Pada Tabel 1 diketahui bahwa terjadi pertumbuhan khamir yang tinggi pada pengamatan 24 jam pertama ini sesuai dengan penelitian Wahono dkk., (2011) yang menyatakan bahwa khamir tumbuh pesat pada 24 jam pertama kemudian turun setelah 48 jam dan 72 jam pengamatan. Namun pembeda dalam penelitian ini adanya sedikit kenaikan pada perlakuan kadar gula $30 \%$ sampai $60 \%$. Kenaikan ini mungkin disebabkan sel khamir yang hidup masih bisa memanfaatkan kadar gula yang tersisa untuk proses kehidupan. Konsentrasi gula optimal untuk pertumbuhan khamir dicapai pada konsentrasi gula $30 \%$.

Di sisi lain, proses fermentasi biasanya menghasilkan senyawa asam yang menyebabkan penurunan pH medium (Azisa dkk., 2012). Kondisi yang sama terjadi pada penelitian ini (Tabel 2) yaitu terjadi penurunan $\mathrm{pH}$ yang awalnya diatur pada $\mathrm{pH} \quad 5.5$ mengalami penurunan yang semula $\mathrm{pH} 5.24$ pada perlaukan tanpa gula menjadi $\mathrm{pH} 4.76$ pada perlakuan gula tertinggi.

Fermentasi gula menjadi alkohol melalui proses glikolisis yang menghasilkan senyawa antara bersifat asam seperti asam piruvat dan asetaldehida yang akan memengaruhi kondisi medium pertumbuhan (Bergman, 2001). Penurunan $\mathrm{pH}$ yang ekstrem bisa menyebabkan terganggunya proses fermentasi karena khamir hanya mampu hidup pada $\mathrm{pH}$ asam ringan, sehingga kadang kala perlu dijaga penurunan $\mathrm{pH}$ ini agar tidak terlalu tajam. Perubahan $\mathrm{pH}$ tidak terlihat lagi secara nyata setelah $\mathrm{pH}$ medium mencapai $\mathrm{pH}$ sekitar 4,8 dan cenderung stabil. Kondisi ini terlihat pada penggunaan gula cair pada kadar $30 \%$.

Tabel 1. Perubahan Total Sel Khamir (dalam juta sel/ml) pada Fermentasi Sari Temulawak

\begin{tabular}{ccccccc}
\hline \hline Waktu pengamatan & Gula 0\% & Gula 15\% & Gula 30\% & Gula 45\% & Gula 60\% & Gula 75\% \\
\hline \hline $\mathbf{2 4}$ jam & $410 \mathrm{a}$ & $455 \mathrm{ab}$ & $510 \mathrm{~b}$ & $587 \mathrm{c}$ & $600 \mathrm{c}$ & $468 \mathrm{ab}$ \\
$\mathbf{4 8}$ jam & $365 \mathrm{a}$ & $387 \mathrm{a}$ & $118 \mathrm{~b}$ & $129 \mathrm{~b}$ & $174 \mathrm{~b}$ & $131 \mathrm{~b}$ \\
$\mathbf{7 2}$ jam & $123 \mathrm{a}$ & $170 \mathrm{a}$ & $251 \mathrm{~b}$ & $266 \mathrm{~b}$ & $201 \mathrm{ab}$ & $96 \mathrm{a}$ \\
\hline
\end{tabular}

Keterangan : angka yang diikuti huruf sama pada baris yang sama tidak ada beda nyata $\alpha 95 \%$ 
Optimalisasi Gula Cair dan pH Medium untuk Fermentasi Alkohol

Tabel 2. Perubahan $\mathrm{pH}$ Pada Fermentasi Sari Temulawak

\begin{tabular}{ccccccc}
\hline \hline Waktu pengamatan & Gula 0\% & Gula15\% & Gula 30\% & Gula 45\% & Gula 60\% & Gula 75\% \\
\hline \hline 24 jam & $5,1-5,24$ & $4.91-4,95$ & $4,81-4,84$ & 4,80 & $4,79-4,80$ & $4,76-4,77$ \\
48 jam & $5,27-5,38$ & $5,06-5,13$ & $4,92-4,97$ & 4,89 & 4,87 & $4,82-4,83$ \\
72 jam & $5,05-5,08$ & $4,90-4,93$ & $4,77-4,78$ & 4,76 & $4,76-4,77$ & 4,77 \\
\hline \hline
\end{tabular}

Tabel 3. Perubahan Kadar Gula Hasil Fermentasi Sari Temulawak

\begin{tabular}{ccccccc}
\hline \hline Hari pengamatan & Gula 0\% & Gula 15\% & Gula 30\% & Gula 45\% & Gula 60\% & Gula75\% \\
\hline \hline jam & 0 & 3,5 & 7,0 & 10,5 & 14 & 17,5 \\
24 jam & 0 & 2,6 & 5,6 & 9 & $13-13,8$ & $16-17$ \\
48 jam & 0 & 1,9 & 5,2 & 9 & $13-14,6$ & $16,2-16,8$ \\
72 jam & 0 & 2 & 5,0 & 9 & $13,6-14,2$ & $16-16,2$ \\
96 jam & 0 & 2,6 & 4,6 & 8,5 & $11-12,4$ & $14,8-15,8$ \\
\hline \hline
\end{tabular}

Perubahan $\mathrm{pH}$ yang terjadi menunjukkan adanya aktivitas kehidupan khamir yang melakukan proses glikolisis yang dilakukan oleh organisma hidup dalam rangka memperoleh energi dan bahan baku rantai karbon untuk memproduksi senyawa baru dan sel baru (Ho Dac dan Powell, 2014). Namun demikian dalam melakukan proses metabolisme tidak selama terjadi satu arah, tetapi proses metabolisme dapat berjalan dua arah atau berkebalikan sehingga gula yang telah diproses melalui glikolisis dapat lagi disintesis menjadi gula baru melalui proses gluconeogenesis sehingga perubahan gula yang terukur tidak selalu turun secara konsisten, namun dapat kembali naik seperti hasil pengukuran gula pada penelitian ini yang dapat dilihat pada Tabel 3 .

\section{Optimalisasi pH terhadap Pertumbuhan Saccharomyces cerevisiae}

Faktor $\mathrm{pH}$ medium pertumbuhan mikroba adalah satu faktor yang penting diperhatikan. Berdasarkan $\mathrm{pH}$ medium pertumbuhannya, mikroba dibagi tiga kelompok, yaitu kelompok mikroba asidofil yang tumbuh pada medium $\mathrm{pH}$ asam (kurang dari 6), netrofil adalah mikroba yang tumbuh pada $\mathrm{pH}$ netral antara 6 - 7,5 dan basophil yaitu mikroba yang hidup $\mathrm{pH}$ basa di atas 7,5. Saccharomyces cerevisiae termasuk kategori asidofil ringan sampai netrofil yaitu mikroba yang tumbuh pada $\mathrm{pH}$ kisaran 4 - 6 (Sabrina dkk., 2016). Berdasarkan hasil perhitungan banyaknya sel yang tumbuh pada medium sari temulawak yang menggunakan gula cair (Tabel 4), diketahui bahwa pH paling baik adalah 5 terjadi pada pertumbuhan 24 jam.
Setelah lebih dari 24 jam ternyata semua perlakuan menunjukkan penurunan.

Hasil ini berlawanan dengan hasil penelitian Purwitasari dkk. (2004) tentang pertumbuhan khamir pada limbah cair tahu dan air kelapa yang cenderung meningkat dari 4,5 menjadi 5,5. Berdasarkan Tabel 5, nilai $\mathrm{pH}$ selama proses fermentasi 72 jam semakin menurun. Pada awalnya $\mathrm{pH}$ di atur dari $4-6$. Pada pengamatan hari pertama (24 jam) semua perlakuan mengalami penurunan pada $\mathrm{pH}$ awal 5 - 6, tetapi ada yang relatif tidak berubah, yaitu pada perlakuan $\mathrm{pH}$ awal 4 dan 4,5 . Penurunan $\mathrm{pH}$ terus terjadi sampai pengamatan 48 jam menjadi kisaran 3,96-4,88 dan mulai stabil pada jam ke-72 pada kisaran 3,84-4,78. Penurunan $\mathrm{pH}$ disebabkan oleh adanya asam-asam organik seperti asam fosfoenol piruvat, asam piruvat, asam asetaldehida dan asam laktat yang terbentuk selama proses fermentasi (Ismaryana dkk., 2012), maupun asam sitrat, asam ketoglutarat, asam malat dan asam asetoasetat sebagai hasil siklus Krebs (Lin dkk., 2009). Menurut Ismaryana dkk. (2012) asam-asam yang terbentuk seperti asam asetat, asam piruvat, dan asam laktat dapat menurunkan $\mathrm{pH}$, sedangkan asam-asam lainnya seperti asam butirat dan asam lemak lainnya hanya sedikit berpengaruh dalam penurunan $\mathrm{pH}$ cairan. Kecenderungan media fermentasi semakin asam disebabkan amonia yang digunakan sel khamir sebagai sumber nitrogen diubah menjadi ion ammonium yang akan menggabungkan diri ke dalam sel sebagai asam amino. Dalam proses ini $\mathrm{H}^{+}$ditinggalkan dalam medium, sehingga semakin lama waktu 
fermentasi semakin rendah $\mathrm{pH}$ media (Nurdyastuti, 2006).

Derajat keasaman akan memengaruhi kecepatan fermentasi, $\mathrm{pH}$ yang optimal untuk pertumbuhan khamir adalah 4 - 4,5 (Budiyanto, 2003). Berdasarkan hasil pengamatan $\mathrm{pH}$ tersebut, dapat diketahui bahwa setelah 72 jam fermentasi mulai berjalan kurang efektif yang disebabkan oleh tingkat keasaman larutan fermentasi yang semakin menurun. Lopez dkk. (2009) menyatakan, $\mathrm{pH}$ pertumbuhan khamir yang baik antara 3 - 6. Perubahan $\mathrm{pH}$ dapat mempengaruhi pembentukan hasil samping. Pengaruh $\mathrm{pH}$ terhadap pertumbuhan khamir juga tergantung pada konsentrasi gula. Selain itu, disebutkan pula bahwa $\mathrm{pH}$ akan memengaruhi kecepatan fermentasi, $\mathrm{pH}$ optimal untuk pertumbuhan khamir adalah 4,0 - 4,5. Oleh karena itu, indikator $\mathrm{pH} /$ tingkat keasaman dapat dijadikan acuan untuk menentukan waktu optimal dan berakhirnya proses fermentasi bioetanol dengan bahan baku gula cair dengan penambahan sari temulawak.

\section{Produksi Alkohol dari Sari Temulawak yang Ditambah Gula Cair}

Bioetanol atau etanol dari proses fermentasi merupakan salah satu sumber energi alternatif yang potensial untuk dikembangkan (Ho Dac dan Chris, 2014). Bioetanol lebih ramah lingkungan daripada bahan bakar fosil, dan $\mathrm{CO}_{2}$ yang dihasilkan oleh hasil buangan mesin akan diserap oleh tanaman, selanjutnya tanaman tersebut digunakan sebagai bahan baku pembuatan bahan bakar mesin, dan seterusnya (Maurice, 2011). Bioetanol merupakan alkohol yang paling sering digunakan dalam kehidupan sehari-hari. Bioetanol selain sebagai bahan bakar, dimanfaatkan sebagai bahan baku industri atau senyawa kimia lain, bahan pelarut industri dan desinfektan. Aryani dkk. (2004) menyatakan bahwa bioetanol dapat dibuat dari bahan yang mengandung gula sederhana, pati maupun bahan berserat melalui proses fermentasi. Masingmasing bahan berbeda cara pengolahannya untuk bisa dijadikan bioetanol. Menurut Retno dan Nuri (2011), produksi bioetanol dengan menggunakan bahan berpati harus diawali dengan proses pemecahan pati menjadi gula sederhana atau glukosa melalui metode hidrolisis asam atau enzimatis. Produksi bioethanol bisa langsung tanpa hidrolisis pati bila menggunakan bahan gula sederhana seperti sukrosa, glukosa dan fruktosa. Selama ini bahan baku produksi etanol oleh khamir $S$. cerevisiae menggunakan molase, suatu bahan karbohidrat cair yang harganya relatif murah (Wardani dan Fenty, 2013). Namun bahan ini banyak juga dimanfaatkan untuk berbagai proses fermentasi menghasilkan asam organik seperti asam glutamat sehingga harganya menjadi mahal. Selain itu, ketersediaan molase mulai terbatas karena molase ini hasil sampingan industri gula pasir yang bersifat musiman.

Saat ini ada produk karbohidrat cair baru merupakan hasil sakharifikasi amilum tapioka dengan komposisi fruktosa sekitar 55\% dan glukosa $35 \%$ ditambah bahan lain yang belum diketahui. Harga bahan ini relatif sama dengan molase dan ketersediaannya cukup melimpah. Pada penelitian hasil fermentasi alkohol menggunakan $S$. cerevisiae menghasilkan alkohol dengan kadar maksimal 3\%. Menurut Rochani dkk. (2016), bioetanol memiliki massa molekul relatif $46,07 \mathrm{~g} / \mathrm{mol}$, titik beku $-114,1^{\circ} \mathrm{C}$, titik didih normal $78.32{ }^{\circ} \mathrm{C}$, densitas pada $20{ }^{\circ} \mathrm{C}$ $0,7893 \mathrm{~g} / \mathrm{mol}$, sangat larut air dengan viskositas pada $20{ }^{\circ} \mathrm{C}$ sebesar $1,17 \mathrm{cP}$, Selain itu alkohol memiliki kalor jenis spesifik $0,579 \mathrm{kal} / \mathrm{g}{ }^{\circ} \mathrm{C}$, kalor pembakaran pada $25^{\circ} \mathrm{C} 7092,1 \mathrm{kal} / \mathrm{g}$ Kalor penguapan $78,32{ }^{\circ} \mathrm{C} 200,6 \mathrm{kal} / \mathrm{g}$. Berdasarkan pengukuran kandungan alkohol menggunakan Gas kromatografi yang hasilnya tertuang pada Tabel 6 diketahui bahwa semakin tinggi kadar gula yang digunakan semakin banyak alkohol yang dihasilkan (Khak dkk., 2014). Tabel 8 menunjukkan kadar alkohol yang terukur yaitu berkisar dari 0,245\% sampai dengan 2,097\%. Kadar alkohol tertinggi diperoleh pada kadar gula sebesar $75 \%$ yaitu $2,097 \%$, namun bila dilihat efisiensi nya tertinggi pada penggunaan gula cair sebanyak 45\%. Hasil ini sesuai dengan penelitian Aziaa dkk (2012). 
Optimalisasi Gula Cair dan pH Medium untuk Fermentasi Alkohol

Tabel 4. Hasil Perhitungan Total Sel Khamir S. cerevisiae (juta sel/ml) pada Fermentasi Sari Temulawak

\begin{tabular}{cccccc}
\hline \hline Waktu pengamatan & pH 6 & pH 5,5 & pH 5 & pH 4,5 & pH 4 \\
\hline \hline $\mathbf{1}$ & $244 \mathrm{a}$ & $222 \mathrm{a}$ & $338 \mathrm{~b}$ & $210 \mathrm{a}$ & $265 \mathrm{a}$ \\
\hline $\mathbf{2}$ & $231 \mathrm{a}$ & $159 \mathrm{~b}$ & 189 & $155 \mathrm{~b}$ & $177 \mathrm{~b}$ \\
\hline $\mathbf{3}$ & $55 \mathrm{a}$ & $44 \mathrm{a}$ & $37 \mathrm{a}$ & $19 \mathrm{~b}$ & $16 \mathrm{~b}$ \\
\hline \hline
\end{tabular}

Keterangan : angka yang diikuti huruf sama tidak beda nyata pada $\alpha 95 \%$

Tabel 5. Perubahan pH Medium Selama Proses Fermentasi Sari Temulawak

\begin{tabular}{cccc}
\hline \hline pH awal & $\mathbf{2 4}$ jam & 48 jam & 72 jam \\
\hline \hline $\mathbf{4}$ & $3.73-4.06$ & $3.96-4.08$ & $3.84-4.09$ \\
$\mathbf{4 . 5}$ & $4.25-4.3$ & $4.44-4.53$ & $4.55-4.68$ \\
$\mathbf{5}$ & $4.39-4.49$ & $4.44-4.77$ & $4.55-4.65$ \\
$\mathbf{5 . 5}$ & $4.48-4.5$ & $4.77-4.78$ & 4.68 \\
$\mathbf{6}$ & $4.58-4.66$ & $4.87-4.88$ & $4.76-4.78$ \\
\hline \hline
\end{tabular}

Tabel 6. Perubahan Kadar Gula Selama Proses Fermentasi Sari Temulawak

\begin{tabular}{cccccc}
\hline Waktu pengamatan & pH 4,0 & pH 4,5 & pH 5,0 & pH5,5 & pH6,0 \\
\hline \hline 0 jam & 7,0 & 7,0 & 7,0 & 7,0 & 7,0 \\
$\mathbf{2 4}$ jam & $5,2-8,2$ & $6,0-6,8$ & $5,0-5,2$ & $4,5-4,6$ & 5,0 \\
$\mathbf{4 8}$ jam & $5,6-8,0$ & $5,8-6,4$ & 4,6 & $4,2-4,6$ & $3-3,8$ \\
$\mathbf{7 2 j a m}$ & $5,6-7,4$ & $5,8-6,4$ & $4,4-4,6$ & $4,2-4,6$ & $4,2-4,8$ \\
96 jam & $5,0-6,6$ & $5,6-6,0$ & $4,4-4,6$ & $4,0-4,6$ & $4,0-4,4$ \\
\hline \hline
\end{tabular}

Tabel 7. Hubungan pH dan Kadar Alkohol yang Dihasilkan Fermentasi Sari Temulawak

\begin{tabular}{llllll}
\hline \hline pH medium & 4 & 4,5 & 5,0 & 5,5 & 6,0 \\
Kadar alkohol \% & $1,569 \mathrm{a}$ & $2,115 \mathrm{a}$ & $9,278 \mathrm{~b}$ & $2,305 \mathrm{a}$ & $1,732 \mathrm{a}$ \\
\hline \hline
\end{tabular}

Keterangan: angka yang diikuti huruf sama tidak beda nyata $\alpha 95 \%$

Tabel 8. Produksi Alkohol oleh Saccharomyces cerevisiae pada Substrat Gula Cair

\begin{tabular}{lcccccc}
\hline \hline Konsentarsi Gula cair & $\mathbf{0}$ & $\mathbf{1 5 \%}$ & $\mathbf{3 0 \%}$ & $\mathbf{4 5 \%}$ & $\mathbf{6 0 \%}$ & $\mathbf{7 5 \%}$ \\
Kandungan Alkohol & $0,067 \%$ & $0,245 \%$ & $0,487 \%$ & $1,474 \%$ & $1,739 \%$ & $2,097 \%$ \\
Efisiensi & 0 & $1,63 \%$ & $1,62 \%$ & $3,275 \%$ & $2,898 \%$ & 2,796 \\
\hline \hline
\end{tabular}

\section{Simpulan}

Gula cair dapat digunakan sebagai sumber karbon dan energi bagi khamir S. cervisiae untuk fermentasi alkohol sari temulawak. Kadar gula cair yang optimal adalah $45 \%$ dengan efisiensi hasil alkohol 3,275\%. Medium yang baik untuk pertumbuhan khamir dan produksi alkohol yaitu pada $\mathrm{pH} 5$.

\section{Daftar Pustaka}

Aryani, D., Tjahyadi, P. dan Ratna, S. 2004. Fermentasi Etanol dari Ubi Jalar (Ipomoea batatas) oleh Kultur Campuran Rhizopus oryzae dan
Saccharomyces cerevisiae. Jurnal Bioteknologi, 1 (1): 13-18,

Atmodjo, P. Kianto, Narindri, B., Harsono, A., dan Edison, A. 2016. Pengaruh Ekstrak Temulawak pada Fermentasi Alkohol dari Molase Substrate oleh Saccharomyces cerevisiae. Biota: Jurnal Ilmiah Ilmu-Ilmu Hayati, 1(3): 132-137

Bergman, L.W. 2001. Growth and Maintenance of Yeast Two-Hybrid Systems. Volume 177 of the series Methods in Molecular Biology pp 9-14.

Hatmanti, A. 2000. Pertumbuhan Saccharomycopsos fibuligera dan Saccharomyces cerevisiae pada Fermentasi Etanol Kulit Pisang Cavendish pada $\mathrm{pH}$ awal yang berbeda. Widyariset, vol 1 . Kandidat Peneliti, Balitbang Lingungan Laut, Puslitbang Oseanologi, LIPI. 
Ismaryana, S., Alfitri, Sadiah, D., Rahman, D. dan Safari A. 2012. Kinerja Fermentasi Ragi Saccharomyces cerevisiae Pada Media VHG Dengan Variasi Konsentrasi Ekstrak Ragi Sebagai Sumber Nitrogen Untuk Produksi Bioetanol. Conference Papper. Research Gate. Oktober 2016.

Khak, M., Ri Ni Rohmatningsih, dan Purwito, 2014. Optimalisasi Fermentor Untuk produksi Etanol dan Analisis Hasil fermentasi Menggunakan Gas Kromatografi. Jurnal Matematika, Saint, dan Teknologi, 15 (1) : 12-20.

Lin, Y., Zhang, W., Li, C., Sakakibara, K., Tanaka, S. dan Kong, H. 2012. Factors affecting ethanol fermentation using Saccharomyces cerevisiae BY4742. Jurnal Biomass and Bioenergy, 47: 395-401.

López, F., Arroyo, N., Orlić, S., Querol, A. dan Barrio, E. 2009. Effects of temperature, $\mathrm{pH}$ and sugar concentration on the growth parameters of Saccharomyces cerevisiae, S. kudriavzevii and their interspecific hybrid. International Journal of Food Microbiology, 131: 120-127

Maurice, M.L. 2011.Factors Effecting Ethanol Fermentation Via Simultaneous Saccharification and Fermentation A study to determine the optimal operating conditions to convert cellulosic biomass into ethanol during enzymatic hydrolysis and microbial fermentation. Massachusetts: Worecester Polytechnic Institute

Nurdyastuti, I. 2006. Teknologi proses produksi bioethanol. Makalah Penelitian Prospek Pengembangan Bio-fuel sebagai Substitusi Bahan Bakar Minyak. Hal 75-83

Pinem, I.H. 1999. Studi Fermentasi Alkohol Dari Temulawak Untuk Mempersiapkan Bahan Minuman Anggur. Skripsi Fakultas Biologi Univ Kristen Duta Wacana. Yogyakarta

Purwitasari, E., Pangastuti, A. dan Setyaningsih, R. 2004. Pengaruh Media Tumbuh terhadap Kadar Protein Saccharomyces cerevisiae dalam Pembuatan Protein Sel Tunggal. Bioteknologi 1, (2): 37-42.

Rahmawati, N., Budiarti, R.S. dan Harlis. 2017 Kajian Pembuatan Gula Cair Berbahan Dasar Kulit
Singkong (Manihot utilissima Pohl.) Dengan Pemanfaatn Bakteri Bacillus licheniformis. Artikel Ilmiah Fakultas keguruan dan Ilmu Pendidikan Univ Jambi 10 halaman.

Retno, T.D. dan Nuri, W.R. 2011. Pembuatan Bioetanol dari Kulit Pisang . Prosiding Seminar Nasional Teknik Kimia "Kejuangan” ISSN 1693 - 4393 Pengembangan Teknologi Kimia untuk Pengolahan Sumber Daya Alam Indonesia Yogyakarta.

Rochani, A., Yuniningsih, S. dan Ma'sum, Z. 2016 Pengaruh Konsentrasi Gula Larutan Molase Terhadap Kadar Etanol Pada Proses Fermentasi. Jurnal Reka Buana, 1 (1): 43-48.

Sabrina, F., Sri, N.R. dan Anton, M. 2016. Uji Potensi Fermentasi Etanol Beberapa Yeast yang Diisolasi dari Daerah Malang, Jawa Timur dengan Metode SDN (Soil Drive Nutrient). Jurnal Sain dan Seni ITS, 5 (2): 2337-3520

Sudarmadji, S., Haryadi, B. dan Suhardi. 1997. Prosedur Analisa untuk Bahan Makanan dan Pertanian. Penerbit Liberty, Yogyakarta

Wahono, S.K., Damayanti, E., Rosyida, V.T. dan Sadyatu, E.I. 2011. Laju Pertumbuhan Saccharomyces cerevisiae pada Proses Fermentasi Pembentukan Bioetanol dari Biji Sorgum (Sorghum bicolor L.) Conference: Conference: Proceedings of National Seminar on Chemical Engineering and Processes - Diponegoro University, Semarang, Indonesia, ISSN: 14114216

Wardani, A.K. dan Fenty, N.E.P. 2013. Produksi Etanol Dari tetes Tebu Oleh Saccharomyces cerevisiae Pembentuk FlokK (NRRL - Y 265). AGRITECH, 33 (2): 131-140.

Yumaihana, Y. dan Aini, Q. 2009. Pemanfaatan tebu untuk produksi bioetanol. Diksesl tanggal 28 Agustus 2016, dari: http://ditjenbun.deptan.go.id/ bbp2tpsur/.../bioetanol.pdf 